UDC 378.147.091.31-059.1

DOI: https://doi.org/10.31470/2415-3729-2020-12-145-162

\title{
Forms and Methods of Professional Training Future Teachers for Tutoring in Terms of Education's Individualization
}

\section{Kateryna Osadcha}

Doctor of Science in Pedagogy, Associate professor, Associate professor of the Department of Informatics and Cybernetics, Bogdan Khmelnitsky Melitopol State Pedagogical University, $\triangle$ 20, Hetmanska Str., Melitopol, Zaporizhzhia region, Ukraine, 72312 E-mail: okp@mdpu.org.ua ORCID: http://orcid.org/0000-0003-0653-6423

Date of receipt of the article: September 28, 2020 Article accepted for publication: November 22, 2020

\section{Форми та методи професійної підготовки майбутніх учителів до тьюторської діяльності в умовах індивідуалізації навчання}

\section{Катерина Петрівна Осадча}

Доктор педагогічних наук, доцент, Доцент кафедри інформатики і кібернетики, Мелітопольський державний педагогічний університет імені Богдана Хмельницького,

$\triangle$ вул. Гетьманська, 20, Мелітополь, Запорізька обл., Україна, 72312

Дата надходження статті: 28 вересня 2020 р. Стаття прийнята до друку: 22 листопада 2020 р. 


\section{Abstract}

The article presents the results of research aimed at analysis and generalization of expedient forms and methods of professional training for future teachers to tutoring. The purpose of the article is to determine the appropriate forms and methods of professional training of future teachers for tutoring.

The basis of the research appropriate forms and methods of professional training in higher education institutions were publications of domestic and foreign scientists in two areas: 1) works, which devoted to the problems of selection of appropriate forms and methods of professional training of future teachers; 2) works on the forms and methods of tutoring used in practice.

Methods of analysis, synthesis and generalization were used to establish appropriate forms and methods of professional training for future teachers to tutoring.

The results. The following forms of education are considered as: tutorial, which is used as a final lesson to deepen students' knowledge of one of the sections from the course; consultations as a discussion of important issues for personal development and education of the student; educational event that involves learning in action and involvement in initiative forms of knowledge acquisition; pedagogical practice based on the principles of consistency, interdisciplinary and integrative in organizations that practice tutoring.

The following specific methods of professional training for future teachers to tutoring are identified: a case method, which based on the discussion from practical situations of tutoring; debates in which students learn to argue their point of view and refute the opposite; a method of conversation that allows you to work with questions of tutors or questions of the tutor to the ward during tutoring; portfolio method, which is an effective tool for self-evaluation; interactive methods that promote the development of the communicative component for tutoring competence in future teachers. 
Conclusions. As a result of research on the basis of studying literary sources it is established that in the course of professional preparation for future teachers to tutoring activity both traditional and specific forms of training are applied. Tutorials, consultations, and educational events are singled out in the study as specific forms of professional training of future teachers for tutoring. It is determined that the appropriate methods of professional training for future teachers to tutoring are active methods, portfolio method, conversation method, problem method, interactive methods. Among the interactive methods, special attention is paid to such as lecture with the inclusion of conversation, problem lecture, interactive seminar, consultation, «round table», group and intergroup discussion, «brainstorming», business and educational games.

Key words: tutoring, professional training, future teachers, forms of education, teaching methods, individualization.

\section{References}

1. Cheng, Y.C., Chow, K.W. \& Tsui, K.T. (2001). New Teacher Education for the Future : International Perspectives. Hong Kong [in English].

2. Hladush, V.A. \& Lysenko, H.I. (2014). Pedahohika vyshchoi shkoly : teoriia, praktyka, istoriia [Higher school pedagogy: theory, practice, history]. Dnipropetrovsk [in Ukrainian].

3. Gordon, E., Morgan, R., O’Malley, Ch. \& Ponticell, J. (2010). Revolyutsiya v tyutorstve: prikladnoye issledovaniye peredovogo opyta. voprosov politiki i dostizheniy uchashchikhsya [The Tutoring Revolution: Applying Research for Best Practices, Policy Implications, and Student Achievement]. Izhevsk: ERGO [in Russian].

4. Gubanova, A.A. (2016). Metodyka provedennia navchalnykh zaniat $\mathrm{z}$ fizyky $\mathrm{u}$ formi tiutoriala [Methodology of teaching physics in the form of a tutorial]. Scientific notes. Series: Problems of physic-mathematical and technological education methodology, 2 (9), 100-107 [in Ukrainian]. 
5. Dubaseniuk, O.A., Semeniuk, T.V. \& Antonova, O.E. (2003). Profesiina pidhotovka maibutnoho vchytelia do pedahohichnoi diialnosti [Professional training of the future teacher for pedagogical activity]. Zhytomyr: Zhytomyr. derzh. ped. un-t [in Ukrainian].

6. Yeremeieva, V.M. (2002). Pedahohichna tekhnolohiia pidhotovky maibutnikh uchyteliv do indyvidualizatsii navchannia uchniv [Pedagogical technology of teacher training for individualization of teaching pupils]. Extended abstract of Doctor's thesis. Kiev [in Ukrainian].

7. Ivashchenko, M.V. Osoblyvosti realizatsii tekhnolohii tiutorskoi diialnosti [Features technology tutor's activities] (2009). Pedagogics, Psychology, Medical-Biological Problems of Physical Training and Sports, 6, 68-72 [in Ukrainian].

8. Kovaleva, T.M. (2010). Materialy kursa «Osnovy t'jutorskogo soprovozhdenija v obshhem obrazovanii»: lekcii 14 [Course materials "Basics of tutoring in general education»: lectures 1-4]. Moskva : Pedagogicheskij universitet «Pervoe sentjabrja» [in Russian].

9. Krivshenko, L.P. Vayndorf-Sysoyeva, M.E. et al. (2010). Pedagogika [Pedagogics]. Moskva : TK Velbi. Izd-vo Prospekt [in Russian].

10. Kutsevol, O.M. (2007). Teoretyko-metodychni osnovy rozvytku kreatyvnosti maibutnikh uchyteliv literatury [Theoretical and methodical foundations for the development of future literature teachers' creativity]. Extended abstract of Doctor's thesis. Kiev [in Ukrainian].

11. Loginov, D.A. (2013). Organizatsiya tyutorskogo soprovozhdeniya obrazovatelnogo protsessa [The organization of the tutorial support of educational process]. Economics of education, 1, 169-173. [in Russian].

12. Osadcha, K.P. (2020). Teoretyko-metodolohichni zasady profesiinoi pidhotovky maibutnikh uchyteliv do tiutorskoi diialnosti [Theoretical and methodological fundamentals of 
vocational training of future teachers for tutoring]. Dissertation for the degree of Doctor of Pedagogical Sciences. Melitopol [in Ukrainian].

13. Osadchiy, V.V. (2010). Metody, formy ta zasoby profesiinoi pidhotovky uchyteliv-tiutoriv $\mathrm{v}$ umovakh dystantsiinoi formy navchannia [Methods, forms and facilities of professional preparation of teachers-tutors in the conditions of the controlled from distance form of teaching]. Pedagogics, Psychology, Medical-Biological Problems of Physical Training and Sports, 6, 82-86 [in Ukrainian].

14. Kovaleva, T.M. et al. (2012). Professiya «tyutor» [The profession «tutor»]. Moskva-Tver : «SFK-ofis» [in Russian].

15. Sichkaruk, O. (2006). Interaktyvni metody navchannia u vyshchii shkoli [Interactive methods of teaching at high school]. Kiev: Takson. [in Ukrainian].

16. Smolyaninova, O.G.. Bekuzarova, N.V.. Ermolovich, E.V. \& Sedykh, T.V. (2015). Programma podgotovki tyutorov V Sibirskom federalnom universitete. Professionalnoye obrazovaniye v Rossii i za rubezhom [Tutor training program at the Siberian Federal University]. Professional education in Russia and abroad, 4 (20), 99-105 [in Russian].

17. Dubaseniuk, O.A. (Ed). (2001). Tekhnolohii profesiinopedahohichnoi pidhotovky maibutnikh uchyteliv [Technologies of professional and pedagogical training of future teachers]. Part 2 : Tekhnolohii sotsialno-pedahohichnoi pidhotovky maibutnikh uchyteliv [Technologies of socio-pedagogical training of future teachers]. Zhytomyr [in Ukrainian].

18. Sergeyeva, V.P. (Ed). (2016). Tyutor v obrazovatelnom prostranstve [Tutor in the educational space]. Moskva : INFRA$\mathrm{M}$ [in Russian].

19. Aleshchenko, S.V. (Ed). (2014). Tyutorskoye soprovozhdeniye detey s OVZ [Tutoring of children with disabilities]. Tomsk : OGKOU «Tsentr PMSS» [in Russian].

20. Shramko, N.V. (2018). Osnovy tyutorstva [Fundamentals of tutoring]. Ekaterinburg [in Russian]. 


\section{Вступ}

Нині загальна середня освіта потребує не лише учителя, який досконало володіє предметними знаннями i здатний передавати їх своїм учням у процесі навчання, а й учителя, який адаптується до нових вимог інформаційного суспільства і здатний здійснювати педагогічний супровід індивідуальних освітніх програм учнів відповідно до задекларованих в Концептуальних засадах реформування середньої школи (2016) завдань (урахування індивідуального темпу навчання, індивідуальних можливостей та особливостей учнів). Тобто учитель має бути здатним виконувати роль тьютора, педагога, який забезпечує розробку і супровід індивідуальної освітньої програми учнів, організує процес індивідуальної роботи 3 учнями 3 виявлення, формування i розвитку їх пізнавальних інтересів, супроводжує процес формування їх особистості (допомагає їм розібратися в успіхах, невдачах, сформулювати особисте замовлення до процесу навчання, вибудувати цілі на майбутне), координує пошук інформації учнями для самоосвіти (Тьютор в образовательном пространстве, 2016 : 3). Також у сфері позашкільної освіти існує попит на тьюторів, що здатні допомогти у розвитку їх індивідуальної програми навчання (з’ясувала, що їй подобається вивчати, чим займатися, підібрала б педагогів для удосконалення їi знань і умінь, підказувала і радила, як і чому навчатися далі) (Осадча, 2020 : 172-172).

Сучасна професійна підготовка майбутніх учителів базується на засадах студентоцентрованого, особистісноорієнтованого та індивідуалізованого навчання. Це зумовлено тим, що заклади вищої освіти прагнуть створити всі умови для розвитку особистісних якостей студентів 3 урахуванням їх індивідуальних особливостей, прагнень та освітніх запитів. Такий підхід дозволить майбутнім учителям зрозуміти цінності тьюторської діяльності (індивідуалізація, свобода вибору, суб'єкт-субєкність, гуманна педагогіка) та втілювати їх у професійну діяльність. 
У зв'язку із цим одним із завдань удосконалення професійної підготовки майбутніх учителів є їх підготовка до здійснення тьюторської діяльності як у системі шкільної так і у позашкільної освіти. Виконання цього завдання в умовах закладу вищої освіти потребує добору доцільних форм і методів професійної підготовки майбутніх учителів до тьюторської діяльності.

Отже, за мету дослідження ми поставили визначення доцільних форм і методів професійної підготовки майбутніх учителів до тьюторської діяльності.

\section{Матеріал і методи досліджень}

Основою дослідження доцільних форм i методів професійної підготовки майбутніх учителів до тьюторської діяльності $\epsilon$ публікації вітчизняних та закордонних науковців, присвячені проблемам відбору доцільних форм i методів професійної підготовки майбутніх учителів (Сремеєва, 2002), (Куцевол, 2007), (Cheng, Chow, Tsui, 2001) та застосовуваним у практиці формам і методам тьюторської діяльності (Профессия «тьютор», 2012), (Гордон, Морган, О’Мэлли, Понтиселл).

У дослідженні форм професійної підготовки майбутніх учителів до тьюторської діяльності виходимо з того, що форма розглядається у дидактиці в двох значеннях: як форма навчання і як форма організації навчання. Форма навчання як дидактична категорія означає зовнішню сторону організації освітнього процесу, залежить від цілей, змісту, методів і засобів навчання, матеріальних умов, складу учасників освітнього процесу та інших його елементів. Існують різні форми навчання, що поділяються за кількістю учнів, часом і місцем навчання, порядком його здійснення. Виділяють індивідуальні, групові, фронтальні, колективні, парні, аудиторні та позааудиторні форми навчання. Форма організації навчання - це конструкція окремої ланки процесу навчання, певний вид заняття (урок, лекція, семінар, екскурсія, факультативне заняття, іспит і т.д.) (Крившенко, 
Вайндорф-Сысоева та ін., 2010 : 207-208). Згідно Закону України «Про вищу освіту» навчання у ЗВО здійснюються за очною (денна, вечірня) і заочною (дистанційна) формами, які можуть поєднуватися, а освітній процес у ЗВО здійснюється за такими формами як навчальні заняття, самостійна робота, практична підготовка, контрольні заходи.

Досліджуючи методи професійної підготовки майбутніх учителів до тьюторської діяльності, спираємося на положення дидактики вищої школи, що методи навчання $\epsilon$ впорядкованими способами взаємопов'язаної, цілеспрямованої діяльності педагога й студентів, спрямовані на ефективне розв'язання навчально-виховних завдань, що реалізуються через систему прийомів і засобів навчальної діяльності (Гладуш, Лисенко, 2014 : 88).

Методами дослідження означеної проблеми виступають пошук і відбір релевантних статей в електронних каталогах Національної бібліотеки України імені B. I. Вернадського та в пошуковій системі Google Scholar; аналіз і узагальнення наукових публікацій та освітнього процесу ЗВО.

\section{Результати та їхнс обговорення}

Зважаючи на аналіз науково-методичних праць щодо застосування форм у професійній підготовці педагогів (Дубасенюк, Семенюк, Антонова, 2003), (Осадчий, 2010), на нашу думку форми організації навчання майбутніх учителів як тьюторів мають бути різноманітні і спрямовані на закріплення вміння пошуку, накопичення та обробки наукової інформації для забезпечення формування практичних умінь для виконання професійних тьюторських завдань. Крім традиційних форм навчання й організації навчання у 3ВО (групові, фронтальні, колективні, парні, аудиторні та позааудиторні форми навчання), 3 метою підготовки майбутніх учителів до тьюторської діяльності нами виокремлено тьюторіали як форму тьюторського заняття, взаємодії тьюторанта 3 тьютором (Профессия «тьютор», 2012 : 236). Тьюторіал визначається як «зустріч 
тьютора $з$ тим, хто навчається, що розвивається в певній логічній послідовності i вирішує цілі i завдання, які визначаються функціоналом тьютора» (Логинов, 2013 : 170).

Як зазначає А. О. Губанова, при денній формі навчання тьюторіал доцільно використати як підсумкове заняття, під час якого студенти поглиблюють свої знання одного 3 розділів курсу. Підготовка до тьюторіалу полягає у вивчені (або повторенні) навчального матеріалу однієї або декількох тем курсу. Для керівництва самостійною роботою викладач розробляє спеціальні методичні посібники та рекомендує студентам відповідні підручники (Губанова, 2016 : 101).

За Д. А. Логіновим структура тьюторіала має бути такою: знайомство (входження в діяльність), активізація («розморожування»), організація вивчення, організація групової та індивідуальної роботи, організація зворотного зв'язку та рефлексії. По завершенні кожного 3 видів діяльності, відповідного конкретному пункту плану, організовується рефлексія. Етап рефлексіі є завершальним у структурі тьюторіалу, суть якого полягає у виявленні ефективність зустрічі, тобто наскільки вона була корисною кожному 3 тьюторантов (Логинов, 2013).

Важливими формами навчання у процесі професійної підготовки майбутніх учителів до тьюторської діяльності $\epsilon$ консультації, що можуть бути груповими чи індивідуальними. У процесі участі студентів у консультаціях вони набудуть досвіду їх проведення для реалізації цієї форми навчання у своїй майбутній тьюторській діяльності (Осадча, 2020 : 349). Адже для тьютора індивідуальна консультація - це обговорення значущих питань, пов'язаних з особистим розвитком і освітою кожної дитини. Мета такої бесіди полягає в активізації кожного школяра з урахуванням саме його здібностей, особливостей його характеру, навичок спілкування i т.д. на подальшу роботу по формуванню i реалізації своєї освітньої програми. А групова консультація організовується для школярів зі схожими проблемами або освітніми інтересами. У ході такої консультації тьютор 
здійснює кілька видів робіт: мотиваційну (визначенні рівня мотивації школярів на розвиток свого пізнавального інтересу), комунікативну (забезпечення зворотного зв'язку в групі) і рефлексивну (забезпечення розуміння в групі, пошук конструктивного вирішення проблеми) (Тьюторское сопровождение детей с ОВ3, 2014 : 9).

Доцільно у процесі професійної підготовки вчителів до тьюторської діяльності застосовувати специфічну для тьюторської діяльності форму навчання - освітню подію, що спрямована на розвиток освітньої мотивації, побудову та реалізацію ІОП, проєктів та досліджень. Це можуть бути: виставки, екскурсії (на природу, в музеї, в парки тощо), походи у кіно та театри, експедиції, польові дослідження, експерименти, лабораторні практикуми та ін.

Освітня подія - спеціальна форма організації й реалізації освітньої діяльності, побудована як інтенсивна зустріч реальної й ідеальної форм (за Б. Д. Ельконіним). На контрасті зі звичними формами навчання й освіти, подія передбачає навчання у дії, залучення до ініціативних форм породження й оформлення знань. Освітня подія - спосіб ініціювання освітньої активності учнів, діяльнісного залучення до різних форм освітньої комунікації, інтересу до створення і презентації продуктів навчальної й освітньої діяльності (Технології професійно-педагогічної підготовки майбутніх учителів, 2001 : 102). Т. М. Ковалева виділяє такі особливості організації і проведення освітніх подій: освітня подія відповідає культурному зразку («свято», «експедиція», «ініціація», «карнавал», «аукціон» і т.д.); вона тісно пов’язана 3 іншими елементами й історією життя суспільства, учасників; має, з одного боку, розгорнутий етап підготовки, з іншого, - привабливу перспективу; вона включає різні види діяльності і позиції; крім самих учнів, в ній беруть участь інші цікаві, привабливі, успішні люди («лідери», «автори», «експерти» і т.п.); у ході події можлива і доречна комунікація, імпровізація, проба (Ковалева, 2010). 
У процесі професійної підготовки майбутніх учителів до тьюторської діяльності важливого значення набуває навчальна та педагогічна практика, які мають бути організована на принципах послідовності, міжпредметності та інтегративності. При визначенні баз практик пріоритет віддається освітнім організаціям і установам, готовим до довгострокового співробітництва, що практикують тьюторство. Програма практик має бути вибудувана як система послідовних проб професійної діяльності, що поступово ускладнюються (Осадча, 2020 : 350).

Удосконалення професійної підготовки майбутніх учителів та підготовка до здійснення тьюторської діяльності потребує доцільного відбору методів навчання. Як зазначає М. В. Іващенко (Іващенко, 2009), специфіка тьюторської діяльності дозволяє повною мірою використовувати весь арсенал методів, прийомів та засобів навчання, виховання й спілкування традиційного навчання у поєднанні iз специфічними розробками інноваційних моделей. Отже, професійна підготовка вчителів до тьюторської діяльності передбачає використання загально-педагогічних методів навчання: словесні методи (розповідь, пояснення, бесіда, дискусія, лекція, робота з книгою), що дає змогу передати великий обсяг навчальної інформації про тьюторську діяльність; наочні методи (ілюстрування, демонстрування, самостійне спостереження), що дозволяють реалізувати тісний взаємозв’язок слова і наочності в єдності споглядання, абстрактного мислення та практики; практичні методи (вправи, лабораторні, практичні, графічні, дослідні роботи), що потребують великої самостійності студентів і дозволяють їм отримати інформацію у процесі дій, формують практичні вміння та навички.

Особливість ролі активних методів навчання у підготовці тьюторів відмічали Н. В. Бекузарова, Т. М. Ковальова, А. О. Теров, Т. В. Сєдіх, О. Г. Смолянінова, О. В. Срмолович, М. Ю. Череділіна. Для якісної професійної 
підготовки майбутніх учителів до тьюторської діяльності доцільними є активні методи в форматі квазіпрофесійного навчання, що істотно підвищують ефективність навчання. Адже активна взаємодія суб'єктів освітнього процесу здійснюється, доповнюючи теоретичний матеріал організаційно-діяльнісними, імітаційно-моделюючими іграми, аналізом кейсів й іншими інтерактивними методами. Впровадження в освітній процес інтерактивних і активних методів навчання дозволяє сформувати професійні компетентності в галузі педагогічної підтримки i консультування, а також розвиває навички системного аналізу ситуації, прийняття рішень, участі у колективній роботі (Смолянинова, Бекузарова, Ермолович, Седых, 2015 : 104). Серед таких методів доцільними у професійній підготовці учителів до тьюторської діяльності є кейс-метод, що оснований на обговоренні практичних ситуацій; дебати, що являють собою метод організації публічної дискусії, в якій потрібно доказово аргументувати свою точку зору i спростувати протилежну (Шрамко, 2018 : 57).

Зважаючи на те, що основним методом тьюторські супроводу є спеціально організована робота 3 питаннями тьюторантів або власні питання тьютора, що задаються їм під час реалізації кожного з етапів тьюторські супроводу, одним із провідних методів професійної підготовки вчителів до тьюторської діяльності є метод бесіди. Його доцільно використовувати під час семінарських занять, зокрема 3 урахуванням прикладів 3 тьюторської практики, для того, щоб студенти навчилися як у колективі так й індивідуально застосовувати метод бесіди у своїй майбутніх професійній діяльності.

На особливу увагу заслуговує метод портфоліо. Його застосування у покликано навчити студентів формувати власне портфоліо та у майбутній професійній діяльності допомагати своєму підопічному (тьютлранту) в оформленні його портфоліо. Портфоліо застосовується на всіх щаблях 
тьюторські супроводу в початковій, підліткової і старшій школі. У практиці тьюторські супроводу використовується кілька типів портфоліо (тематичне, презентаційне, досягнень). Портфоліо, яке веде учень протягом декількох років, накопичуючи матеріал, структуруючи і видозмінюючи його, допомагає йому самому відстежувати етапи своєї освітньої траєкторії й є для нього ефективним інструментом самооцінки. Тьютор, допомагаючи школяреві організовувати роботу по збору та аналізу матеріалів його портфоліо, одночасно веде і власне педагогічне портфоліо, де записує свої роздуми про тьюторанта, фіксує педагогічні технології, що застосовуються на кожному 3 етапів, i оцінює їх ефективність (Профессия «тьютор», 2012 : 83).

Отже, створюючи своє портфоліо, студенти мають розуміти, що воно може бути кількох типів (тематичне, презентаційне, досягнень). Доцільним буде оформлення портфоліо досягнень, що допомагає оцінювати прогрес у процесі професійної підготовки. У портфоліо досягнень можуть входити: оригінали або копії творчих робіт; відгуки та рецензії викладачів, зовнішніх експертів, які працюють в спеціальній області інтересу; відгуки однолітків, одногрупників і т.п.; виписки з журналу успішності, екрану рейтингового оцінювання і т.п.; супровідний лист викладачатьютора: оцінка роботи i опис перспектив можливого подальшого розвитку; резюме самого студента: короткий опис найбільш важливих з його точки зору досягнутих у цій роботі результатів тощо (Осадча, 2020 : 353).

3 метою удосконалення процесу професійної підготовки майбутніх учителів до тьюторської діяльності важливо впроваджувати інтерактивні методи, а саме такі як: лекція з включенням бесіди (дискусії), проблемна лекція, інтерактивний семінари, консультація, «круглий стіл», групова та міжгрупова дискусія, «мозковий штурм», ділові та навчально-педагогічні ігри (за О. Січкарук (Січкарук, 2006 : 36)). Ці методи дозволяють формувати в майбутніх 
учителів вміння проєктувати освітній процес у спільній діяльності 3 його основними учасниками, аналізувати професійну діяльність, в тому числі власну, в умовах взаємодії. Використання інтерактивних методів сприяє розвитку комунікативного компоненту тьюторської компетентності у майбутніх учителів, що супроводжується розвитком рефлексивних умінь студентів і проявляється в готовності переосмислювати i творчо перетворювати особистий i професійний досвід, залучатися до міжособистісних відношень та ефективної взаємодії.

\section{Висновки}

Отже, на основі аналізу науково-педагогічних праць та власного досвіду педагогічної діяльності для удосконалення ефективності професійної підготовки майбутніх учителів до тьюторської діяльності нами запропоновано поряд із традиційними формами та методами специфічні для професійної підготовки майбутніх учителів до тьюторської діяльності. Серед специфічних форми професійної підготовки майбутніх учителів до тьюторської діяльності у дослідженні виділено тьюторіали, консультації, освітні події. Їх застосування дозволяє студентам оволодіти уявленнями про застосування цих форм у майбутній професійній діяльності як тьюторів. Серед доцільних методів професійної підготовки майбутніх учителів до тьюторської діяльності виділено активні методи, портфоліо, метод бесіди, проблемний метод, інтерактивні методи (лекція 3 включенням бесіди, проблемна лекція, інтерактивний семінар, консультація, «круглий стіл», групова та міжгрупова дискусія, «мозковий штурм», ділові та навчально-педагогічні ігри). Застосування такого комплексу методів у процесі професійної підготовки майбутніх учителів спрямоване на оволодіння студентами цими методами та набуття ними вміння використовувати їх у тьюторсьбкій діяльності. Ці узагальнення дають підстави для подальших досліджень 
оптимальних умов застосування цих форм і методів у професійній підготовці майбутніх учителів до тьюторської діяльності. Перспективність цього дослідження пов'язано $з$ подальшими розробками педагогічних технологій і засобів професійної підготовки майбутніх учителів до тьюторської діяльності.

\section{Лiтература}

1. Cheng Y.C., Chow K.W., Tsui K.T. New Teacher Education for the Future : International Perspectives. Hong Kong, 2001. 550 p.

2. Гладуш В.А., Лисенко ГІ. Педагогіка вищої школи : теорія, практика, історія: навч. посіб. Дніпропетровьск, 2014. $416 \mathrm{c}$.

3. Гордон Э., Морган Р., О’Мэлли Ч., Понтиселл Дж. Революция в тьюторстве: прикладное исследование передового опыта, вопросов политики и достижений учащихся. Ижевск : ERGO, 2010. 332 с.

4. Губанова А.О. Методика проведення навчальних занять 3 фізики у формі тьюторіала. Наукові записки. Серія: Проблеми методики фізико-математичної і технологічної освіти. 2016. Том 2, № 9. С. 100-107.

5. Дубасенюк О.А., Семенюк Т.В., Антонова О.С. Професійна підготовка майбутнього вчителя до педагогічної діяльності : монографія. Житомир: Житомир. держ. пед. ун-т, 2003. 193 с.

6. Єремеєва В.М. Педагогічна технологія підготовки майбутніх учителів до індивідуалізації навчання учнів : автореф. дис... канд. пед. наук : 13.00.04. Київ, 2002. 23 с.

7. Іващенко М.В. Особливості реалізації технології тьюторської діяльності. Педагогіка, психологія та медикобіологічні проблеми фізичного виховання і спорту. 2009. № 6. С. $68-72$.

8. Ковалева Т.М. Материаль курса «Oсновы тьюторского сопровождения в общем образовании» : 
лекции 1-4. Москва : Педагогический университет «Первое сентября», 2010. 56 с.

9. Крившенко Л.П., Вайндорф-Сысоева М.Е. и др.. Педагогика : учебник. Москва : ТК Велби, Изд-во Проспект, 2010. 432 с.

10. Куцевол О.М. Теоретико-методичні основи розвитку креативності майбутніх учителів літератури : автореф. дис... д-ра пед. наук : 13.00.02. Київ, 2007. 44 с.

11. Логинов Д.А. Организация тьюторского сопровождения образовательного процесса. Экономика образования. 2013. № 1. С. 169-173.

12. Осадча К.П. Теоретико-методологічні засади професійної підготовки майбутніх учителів до тьюторської діяльності : дис... д-ра пед. наук : 13.00.04. Мелітополь, 2020. $705 \mathrm{c}$.

13. Осадчий В.В. Методи, форми та засоби професійної підготовки учителів-тьюторів в умовах дистанційної форми навчання. Педагогіка, психологія та медико-біологічні проблеми фізичного виховання $i$ спорту. 2010. Вип. 6. C.82-86.

14. Профессия «тьютор» / Т.М. Ковалева и др.. МоскваТверь : «СФК-офис», 2012. 246 с.

15. Січкарук О. Інтерактивні методи навчання у вищій школі : навч.-метод. Посіб. Київ : Таксон, 2006. 88 с.

16. Смолянинова О.Г., Бекузарова Н.В., Ермолович Е.В., Седых Т.В. Программа подготовки тьюторов в Сибирском федеральном университете. Профессиональное образование в России и за рубежсм. 2015.№ 4 (20). С. 99-105.

17. Технології професійно-педагогічної підготовки майбутніх учителів : навч. посіб. : у 2 ч. / за заг. ред. О.А. Дубасенюк. Житомир : Житомир. держ. пед. ун-т, 2001. Ч. 2 : Технології соціально-педагогічної підготовки майбутніх учителів. 192 с.

18. Тьютор в образовательном пространстве : учеб. пособие / под ред. В. П. Сергеевой. Москва : ИНФРА-М, 2016. 192 c. 
19. Тьюторское сопровождение детей с ОВ3. Методические рекомендации для тьюторов, педагогов, специалистов образовательных учреждений / Сост. Алещенко С.В. Томск : ОГКОУ «Центр ПМСС», 2014. 42 с.

20. Шрамко Н.В. Основь тьюторства: курс лекиій : учебное пособие для студентов высших учебных заведений. Екатеринбург : [б. и.], 2018. 111 с.

\section{Осадча К.П.}

Форми та методи професійної підготовки майбутніх учителів до тьюторської діяльності в умовах індивідуалізації навчання

\section{Анотація}

У статті представлено результати дослідження, спрямованого на аналіз і узагальнення доцільних форм i методів професійної підготовки майбутніх учителів до тьюторської діяльності. На основі вивчення літературних джерел встановлено, що у процесі професійної підготовки майбутніх учителів до тьюторської діяльності застосовуються як традиційні так і специфічні форми навчання. Як специфічні форми професійної підготовки майбутніх учителів до тьюторської діяльності у дослідженні виділено тьюторіали, консультації, освітні події. Визначено, що доцільними методами професійної підготовки майбутніх учителів до тьюторської діяльності є активні методи, метод портфоліо, метод бесіди, проблемний метод, інтерактивні методи. Серед інтерактивних методів особлива увага приділяється таким як лекція 3 включенням бесіди, проблемна лекція, інтерактивний семінар, консультація, «круглий стіл», групова та міжгрупова дискусія, «мозковий штурм», ділові та навчально-педагогічні ігри.

Ключові слова: тьюторська діяльність, професійна підготовка, майбутні вчителі, форми навчання, методи навчання, індивідуалізація. 


\section{Осадчая Е.П.}

\section{Формы и методы профессиональной подготовки будущих учителей к тьюторской деятельности в условиях индивидуализации обучения}

\section{Аннотация}

В статье представлены результаты исследования, направленного на анализ и обобщение целесообразных форм и методов профессиональной подготовки будущих учителей к тьюторской деятельности. На основе изучения литературных источников установлено, что в процессе профессиональной подготовки будущих учителей к тьюторской деятельности применяются как традиционные так и специфические формы обучения. Как специфические формы профессиональной подготовки будущих учителей к тьюторской деятельности в исследовании выделено тьюториалы, консультации, образовательные события. Определено, что целесообразными методами профессиональной подготовки будущих учителей к тьюторской деятельности являются активные методы, метод портфолио, метод беседы, проблемный метод, интерактивные методы. Среди интерактивных методов особое внимание уделяется таким как лекция с включением беседы, проблемная лекция, интерактивный семинар, консультация, «круглый стол», групповая и межгрупповая дискуссия, «мозговой штурм», деловые и учебнопедагогические игры.

Ключевые слова: тьюторские деятельность, профессиональная подготовка, будущие учителя, формы обучения, методы обучения, индивидуализация. 